\title{
Peningkatan Hasil Belajar Dan Keaktifan Belajar IPA Melalui Penerapan Strategi Pembelajaran Inkuiri Pada Siswa SD Negeri 050747 Pangkalan Berandan Tahun Ajaran 2016-2017
}

\author{
Ratna Dewi \\ SD Negeri 050747 Pangkalan Berandan, Kabupaten Langkat, Sumatera Utara, Indonesia \\ Email: ratnadewi@gmail.com
}

\begin{abstract}
Abstrak
Tujuan dalam penelitian ini adalah untuk meningkatkan hasil belajar IPA Melalui Penerapan Strategi Pembelajaran Inkuiri Pada Siswa SD Negeri 050747 Pangkalan Berandan Tahun Ajaran 2016-2017. Penelitian ini merupakan penelitian tindakan kelas dengan metode penelitian deskriptif kualitatif yang terdiri dari 2 siklus. Dari observasi dapat diketahui bahwa nilai hasil belajar siswa mengalami peningkatan. Hal itu dapat dilihat dari perolehan nilai rata-rata siswa pada siklus I yaitu 68,65 dengan persentase ketuntasan $50 \%$ di mana jumlah siswa yang tuntas belajar mencapai 13 orang dari jumlah seluruh siswa sebanyak 26 orang. Pada siklus II hasil belajar siswa semakin meningkat dimana perolehan nilai rata-rata mencapai 80,57 dengan persentase ketuntasan 92,35\% dimana jumlah siswa yang tuntas belajar mencapai 24 orang dari jumlah seluruh siswa sebanyak 26 orang. Hal ini menunjukkan bahwa siswa lebih paham mengikuti pembelajaran IPA melalui Penerapan Strategi Pembelajaran Inkuiri.
\end{abstract}

Kata Kunci: Hasil Belajar; Pembelajaran Inkuiri; IPA

\begin{abstract}
The purpose of this study is to improve the learning outcomes of science through the implementation of Inquiry Learning Strategies In SDN 050747 Pangkalan Gelaran Tahun Teaching 2016-2017. This research is a classroom action research with qualitative descriptive research method consisting of 2 cycles. From the observation can be seen that the value of student learning outcomes have increased. It can be seen from the acquisition of the average value of students in the first cycle is 68.65 with $50 \%$ completeness percentage where the number of students who complete learning reached 13 people from the total number of students as many as 26 people. In the second cycle student learning outcomes are increasing where the average value reaches 80.57 with a percentage of $92.35 \%$ completeness where the number of students who complete learning reached 24 people from the total number of students as many as 26 people. This shows that the students are better understood to follow science lesson through Application of Inquiry Learning Strategy.
\end{abstract}

Keywords: Learning outcomes; Inquiry Learning; Science

\section{A. PENDAhULUAN}

Seiring berjalannya waktu, dunia pendidikan telah mengalami berbagai macam perubahan. Mulai dari kurikulum, strategi pembelajaran, media pembelajaran, Perubahan tersebut termasuk pada sistem pembelajaran. Pembelajaran saat ini harus berpusat pada siswa bukan pada guru. Guru ditekankan lebih berperan sebagai pendamping siswa, atau dengan kata lain guru adalah fasilitator bagi siswa. Pembelajaran juga harus mampu memberi pengalaman belajar bagi siswa. Agar dapat memberi pengalaman belajar yang 
mendalam bagi siswa guru harus mampu memilih strategi pembelajaran yangsesuai dengan tahapan perkembangan dan karakteristik siswa. Pembelajaran dengan metode konvensional yaitu metode ceramah harus sudah diminimalisasikan namun bukan berarti dihilangkan.

Pemerintah dengan PP No 19 Tahun 2005 tentang Standar Nasional Pendidikan menyatakan bahwa salah satu kelompok mata pelajaran untuk jenjang pendidikan dasar adalah kelompok mata pelajaran ilmu pengetahuan dan teknologi yang dimaksudkan untuk mengenal, menyikapi dan mengapresiasi ilmu pengetahuan dan teknologi serta menanamkan kebiasaan berpikir dan berperilaku ilmiah yang kritis, kreatif dan mandiri. Salah satu mata pelajaran yang termasuk dalam kelompok mata pelajaran ilmu pengetahuan dan teknologi adalah IlmuPengetahuan Alam (IPA).

Berdasarkan lampiran Permendiknas No 22 Tahun 2006 tentang Standar Isi untuk SD/MI dijelaskan bahwa IPA adalah mata pelajaran yang berhubungan dengan cara mencari tahu tentang alam secara sistematis, sehingga IPA bukan hanya penguasaan kumpulan pengetahuan yang berupa fakta-fakta, konsep-konsep atau prinsip-prinsip saja tetapi juga suatu proses penemuan. Jelas bahwa pembelajaran yang dilakukan sebaiknya menggunakan strategi-strategi yang mengajak siswa untuk secara aktif menemukan fakta, konsep, prinsip dengan melalui suatu proses sehingga siswa akan memperoleh pengalaman belajar yang mendalam. Selain itu penggunaan media yang nyata, menarik dan dapat diobservasi secara langsung oleh siswa juga harus dilakukan. Pembelajaran dapat dilaksanakan tidak hanya di dalam kelas tanpa menghadirkan media yang menarik bagi siswa, namun pembelajaran dapat pula dilaksanakan di luar kelas dengan memanfaatnya lingkungan sebagai media dan sumber belajarnya.

Berdasarkan hasil observasi tentang pembelajaran IPA di SD Negeri 050747 Pangkalan Berandan peneliti menemukan fakta bahwa pembelajaran IPA di SD Negeri 050747 Pangkalan Berandan secara umum telah berjalan dengan baik. Guru telah menghadirkan media pembelajaran, alat peraga, dan sarana penunjang pembelajaran yang lain. Namun di sisi lain pembelajaran IPA masih terfokus dengan tingginya peran guru dalam pembelajaran. Dalam hal menyiapkan alat peraga misalnya, guru masih banyak melakukannya sendiri. Padahal sebenarnya keterlibatan siswa dalam pembelajaran haruslah dikedepankan.

Selain itu pembelajaran di kelas IV-A SD Negeri Negeri 050747 Pangkalan Berandan masih dilaksanakan dengan belum mengedepankan proses bagi siswa. Pembelajaran masih diisi dengan transfer pengetahuan satu arah dari guru ke siswa meskipun telah dilaksanakan dengan beberapa metode. Siswa belum diajak untuk mengalami proses-proses pembelajaran yang dapat memberi pengalaman belajar.

Strategi pembelajaran yang digunakan harusnya adalah strategi-strategi yang mampu memberi kesempatan kepada siswa untuk menyentuh alam secara langsung. Hal seperti ini masih belum dilaksanakan secara secara maksimal. Adanya berbagai permasalahan di atas memberi dampak yang cukup besar terhadap hasil belajar siswa. Dari data yang peneliti dapatkan bahwa hasil belajar IPA siswa SD Negeri 050747 Pangkalan Berandan pada tahun 2016-2017 masih termasuk rendah jika dibandingkan dengan mata pelajaran yang lain. Memang, IPA tidak menjadi mata pelajaran dengan hasil ulangan paling jelek. Namun, jika diurutkan dari 8 mata pelajaran yang diujikan, IPA ada pada urutan ketiga dari bawah. IPA hanya lebih baik dari Matematika, dan sedikit lebih baik dari Bahasa Jawa. Adanya fakta ini mendorong peneliti untuk melakukan perbaikan pembelajaran agar hasil belajar IPA siswa kelas IV-A SD Negeri 050747 Pangkalan Berandan mengalami peningkatan. 
Pada artikel ini, bagaimana Penerapan Strategi Pembelajaran Inkuiri Untuk Meningkatkan Keaktifan Dan Hasil Belajar IPA Pada Siswa Kelas IV-A SD Negeri 050747 Pangkalan Berandan Tahun Pelajaran 2016-2017 dihasilkan.

\section{B. STRATEGI PEMBELAJARAN INKUIRI}

\section{Konsep Dasar Strategi Pembelajaran Inkuiri}

Menurut Webster's New Collegiate Dictionary kata inkuiri berarti pertanyaanatau penyelidikan. Sedangkan Jean Piaget (dalam Iskandar, 1997:68) mendefinisikan pendekatan inkuiri sebagai pendidikan yang mempersiapkansituasi bagi anak-anak untuk melakukan eksperimen sendiri, mengajukanpertanyaan-pertanyaan dan mencari sendiri jawaban atas pertanyaan yang merekaajukan.

Menurut Gulo (2004:84-85) strategi inkuiri berarti suatu rangkaian kegiatanbelajar yang melibatkan secara maksimal seluruh kemampuan siswa untukmencari dan menyelidiki secara sistemis, kritis, logis, analitis, sehingga merekadapat merumuskan sendiri penemuan dengan penuh percaya diri. Sasaran utama kegiatan mengajar pada strategi ini ialah:

a. Keterlibatan siswa secara maksimal dalam proses kegiatan belajar.

b. Kegiatan belajar di sini adalah kegiatan mental intelektual dan sosial.

c. Keterarahan kegiatan secara logis dan sistematis pada tujuan pengajaran.

d. Mengembangkan sikap percaya pada diri sendiri (self belief) pada dirisiswa tentang apa yang ditemukan dalam proses inkuiri.

Menurut Sumantri dan Permana (1998:164) inkuiri adalah cara penyajian pelajaran yang memberi kesempatan kepada peserta didik untuk menemukan informasi dengan atau tanpa bantuan guru. Tujuan dari inkuiri antara lain:

a. Meningkatkan keterlibatan peserta didk dalam menemukan dan memproses bahan pelajarannya.

b. Mengurangi ketergantungan peserta didik pada guru untuk mendapatkan pengalaman belajarnya.

c. Melatih peserta didik menggali dan memanfaatkan lingkungan sebagai sumber belajar yang tidak ada habisnya.

d. Memberi pengalaman belajar seumur hidup.

Dari berbagai pendapat di depan peneliti dapat merumuskan bahwa strategipembelajaran inkuiri (SPI) adalah suatu strategi pembelajaran yang menempatkansiswa sebagai subjek belajar yang diberi kesempatan secara luas untuk melakukanaktivitas mengamati, meyelidiki, melakukan percobaan dengan menekankan padaproses berpikir kritis dan analitis untuk mencari jawaban atas pertanyaan yangmereka ajukan sendiri dengan atau tanpa bantuan guru. Dalam penelitian ini SPIyang diterapkan adalah jenis guided inquiry.

\section{Prinsip-prinsip Strategi Pembelajaran Inkuiri}

Menurut Piaget (Sanjaya, 2011: 198) pengembangan intelektual anak dipengaruhi oleh 4 faktor, yaitu maturation, physical experience, social experience, dan equilibration. Maturation atau kematangan adalah perubahan fisiologis dan anatomis, yaitu proses pertumbuhan fisik yang meliputi pertumbuhan tubuh, otak dan sistem syaraf seseorang. Sedangkan physical experience adalah tindakan fisik yang dilakukan seseorang terhadap benda-benda yang ada di lingkungan sekitarnya. Selanjutnya social experience diartikan sebagai pengalaman seseorang dalam bersosialisasi dengan orang lain. Yang terakhir 
adalah equilibration, artinya adalah proses penyesuaian antara pengetahuan yang sudah ada dengan pengetahuan baru yang sudah ditemukan.

\section{Langkah-langkah Pelaksanaan Strategi Pembelajaran Inkuiri}

Menurut Sanjaya (2011:201) langkah-langkah pembelajaran yangdilakukan dalam SPI antara lain sebagai berikut:

\section{a. Orientasi}

Langkah orientasi adalah langkah untuk membina suasana atau iklim pembelajaran yang responsif. Kegiatan yang dapat dillakukan tahapan orientasi adalah:

- Menjelaskan topik, tujuan, dan hasil belajar yang diharapkan dapat dicapai olehsiswa;

- Menjelaskan pokok-pokok kegiatan yang harus dilakukan oleh siswa untuk mencapai tujuan;

- Menjelaskan pentingnya topik dan kegiatan belajar.

\section{b. Merumuskan masalah}

Ada beberapa hal yang harus diperhatikan dalam tahapan perumusan masalah, antara lain:

- Perumusan masalah hendaknya dilakukan sendiri oleh siswa, guru hanya bertugas memberikan bimbingan;

- Masalah yang dikaji adalah masalah yang mengandung teki-teki namunsebenarnya jawabannya sudah pasti ada dan guru sebaiknya telah benar-benarmemahami jawaban dari teka-teki ini;

- Konsep-konsep dalam masalah adalah konsep-konsep yang sudah diketahui oleh siswa.

\section{c. Mengajukan hipotesis}

Hipotesis adalah jawaban sementara dari permasalahan yang sedang dibahas.

\section{d. Mengumpulkan data}

Kegiatan ini dilakukan sebagai langkah untuk menguji kebenaran dari hipotesis yang telah diajukan sebelumnya.

\section{e. Menguji hipotesis}

Setelah data yang dapat digunakan untuk menguji hipotesis terkumpul maka langkah selanjutnya adalah menguji hipotesis dengan data-data tersebut.

\section{f. Merumuskan kesimpulan}

Merumuskan kesimpulan ini adalah puncak dari pembelajaran yang dilakukan. Dalam merumuskan kesimpulan ini yang dilakukan adalah mendeskripsikan data-data yang ditemukan disesuaikan dengan pengujian yang telah dilakukan terhadap hipotesis.

Menurut Dalhar dan Liliasari (dalam Iskandar, 1997:69) lima karakteristik inkuri yaitu:

- Situasi yang menyediakan stimulus untuk inkuiri

- Masalah yang akan dicari pemecahannya

- Perumusan masalah

- Pencarian pemecahan masalah

- Kesimpulan yang diperoleh sebagai hasil penyelidikan 


\section{METODE PENELITIAN}

Penelitian ini dilakukan di SD Negeri 050747 Pangkalan Berandan. Jumlah siswa sebanyak 26 orang siswa. Karakteristik siswa tersebut adalah siswa yang rata-rata kemampuannya hampir sama dengan siswa kelas IV lainnya. Metode Penelitian yang digunakan adalah Penelitian Tindakan Kelas (PTK) yang terdiri dari 2 siklus, masingmasing siklus melalui tahap: perencanaan, pelaksanaan tindakan, pengamatan dan Refleksi.

Teknik Pengumpulan data dalam penelitian ini adalah teknik tes. Teknik tes berupa tes tertulis dengan alat pengumpul data dan berupa soal untuk menentukan hasil belajar dan non tes tertulis (observasi) untuk mengukur tingkat keefektifan. Indikator Keberhasilan jika berhasil apabila 80\% siswa kelas IV-A SD Negeri 050747 Pangkalan Berandan Tahun Pelajaran 2016-2017 mendapatkan nilai 75.

\section{HASIL DAN PEMBAHASAN}

\section{Hasil Penelitian}

Sebelum penelitian dilakukan, sebagai IPA, peneliti terlebih dahulu melakukan test awal untuk mengetahui hasil belajar siswa. Namun pada tahap awal ini peneliti tidak meneliti aktivitas siswa selama proses pembelajaran di kelas. Tahap ini, peneliti hanya melakukan instrument test awal, sebelum tindakan dilakukan. Dari hasil tes awal, hasil belajar sangat rendah dan jauh dari KKM. Dari jumlah keseluruhan siswa yang terdiri dari 26 orang hanya 5 orang atau 19,23\% yang tuntas belajar, selebihnya mendapatkan nilai dibawah KKM. Nilai rata-rata keseluruh siswa adalah 61,53.

Tindakan dilakukan pada siklus I, hasil belajar mengalami penigkatan, dari jumlah siswa yang tuntas belajar meningkat dari 5 orang menjadi 13 orang dengan persentase ketuntasan $50 \%$. Hal itu juga dapat dilihat dari peningkatan nilai rata-ratayang diperoleh yaitu 68,65. Pada siklus II, hasil belajar siswa SD Negeri 050747 Pangkalan Berandan semakin meningkat. Hal itu dapat dilihat dari jumlah siswa yang tuntas telah mencapai 24 orang dengan persentase ketuntasan $92,30 \%$. Selain itu nilai rata-ratanya sudah melebihi KKM yang ditentukan pihak sekolah dengan mencapai nilai 80,57. Melihat hasil pada siklus II, peneliti merasa tidak perlu melanjutkan penelitian kesiklus berikutnya karena peneliti sudah merasa puas dengan hasil belajar yang diperoleh.

Sedangkan keaktifan siswa pada saat mengikuti pelajaran IPA masih sangat rendah. Hal itu dapat diketahui dari hasil yang diperoleh bahwa hanya 5 siswa yang sangat aktif belajar, 14 siswa aktif belajar dan sisanya masuk dalam keterangan kurang aktif dan aktif. Melihat persentase ketuntasan yang hanya 57,69\% maka keaktifan belajar siswa masuk dalam kategori D. Pada siklus I, keaktifan siswa pada saat mengikuti pelajaran IPA mengalami peningkatan. Hal itu dapat diketahui dari hasil yang diperoleh bahwa siswa yang sangat aktif belajar berjumlah 7 orang dan siswa yang aktif berjumlah 12 orang. Melihat persentase ketuntasan yang mencapai 73,07\% maka keaktifan belajar siswa masuk dalam kategori B. Pada siklus II, keaktifan siswa selama pembelajaran IPA berlangsung semakin meningkat. Itu terlihat dari jumlah siswa yang sangat aktif 7 orang, siswa yang aktif 13 orang, siswa yang cukup aktif 6 orang sementara siswa yang kurang aktif dan yang tidak aktif tidak ada (0). Melihat hasil persentase ketuntasan yang mencapai 76,92\% maka hasil tersebut masuk pada kategori B. 


\section{Pembahasan}

\section{a. Hasil Belajar Siswa}

Pada tahap sebelum dilakukan tindakan siklus 1, dari keseluruhan jumlah siswa yaitu 26 siswa, hanya 5 siswa yang lulus KKM (70). Dari hasil belajar yang diperoleh oleh siswa dapat dilihat bahwa hanya 19,23\% dengan perolehan nilai rata-rata siswa kelas IVA Negeri 050747 Pangkalan Berandan Tahun Pelajaran 2016-2017hanya 61,53. Kemudian pada siklus 1, rata-rata hasil belajar siswa siklus 1 sebesar 68,65 dengan persentase ketuntasan sebesar 50\%. Dan pada siklus II diadakan perbaikan lagi dan diperoleh ratarata hasil belajar siswa pada siklus II sebesar 80,57 dengan persentase ketuntasan belajar sebesar $92,30 \%$.

\section{b. Keaktifan Siswa Selama Proses Pembelajaran Berlangsung}

Jumlah perolehan skor pada Siklus I pertemuan 1 adalah 15 dengan kategori D (kurang Aktif). Adapun persentasenya sebesar 57,69\%.Pada pertemuan 2 keaktifan selama proses pembelajaran di kelas sudah mengalami peningkatan. Dimana jumlah perolehan skor pada pertemuan 2 adalah 19 dengan kategori B (Aktif) .Adapun persentasenya sebesar 73,07\%. Dan pada siklus II jumlah perolehan skor pada siklus II pertemuan 1 adalah sebesar 20 dengan kategori B (Aktif). Adapun persentasenya sebesar 76,92\% dan pada pertemuan 2 adalah 24 dengan kategori A (Sangat Aktif).Adapun persentasenya sebesar $92,30 \%$.

\section{E. SIMPULAN}

Berdasarkan hasil analisis dan pembahasan yang telah diuraikan padabab sebelumnya, maka dapat disimpulkan sebagai berikut:

1. Terjadi peningkatan Hasil belajar siswa kelas IV-A SD Negeri 050747 Pangkalan Berandan Tahun Pelajaran 2016-2017

2. Terjadi peningkatan Keaktifan siswa selama proses pembelajaran di kelas siswa kelas IV-A SD Negeri 050747 Pangkalan Berandan Tahun Pelajaran 2016-2017.

3. Peningkatan hasil belajar siswa kelas IV-A SD Negeri 050747 Pangkalan Berandan Tahun Pelajaran 2016-2017dapat dilihat dari pra-siklus sebesar 61,53 meningkat di siklus 1 menjadi 68,65

4. Kemudian dari siklus I ke siklus II nilai rata-rata kembali mengalami peningkatan dimana pada siklus 1 sebesar 68,65 meningkat menjadi 80,57.

5. Dengan demikian menunjukkan bahwanilai rata-rata Pra-Siklus sebesar 61,53meningkat menjadi sebesar68,65, pada siklus 1 belum mencapai indikator keberhasilan yang telah ditentukan.

6. Kemudian di siklus 2 hasil belajar meningkat lagi menjadi 80,57. Dimana di siklus 2 indikator keberhasilan telah dicapai.

7. Dengan menerapkan metode Strategi Pembelajaran Inkuiri pada siswa kelas IV-A SD Negeri 050747 Pangkalan Berandan Tahun Pelajaran 2016-2017, maka hasil belajar dan Keaktifan siswa memgalami peningkatan

\section{F. DAFTAR PUSTAKA}

Dalyono, M. 2009. Psikologi Pendidikan. Jakarta: Rineka Cipta.

Dimyati \& Mudjiono. 2002. Belajar dan Pembelajaran. Jakarta: Rineka Cipta.

Gulo. W. 2004. Strategi Belajar Mengajar. Jakarta: PT Gramedia. 
Iskandar, S.M. 1997. Pendidikan Ilmu Pengetahuan Alam. Jakarta: DIKTI.

Sanjaya, W. 2011. Strategi Pembelajaran Berorientasi Standar Proses Pendidikan. Bandung: Kencana Prenada Media.

Suharsimi, A. 2007. Dasar-dasar Evaluasi Pendidikan. Jakarta: Bumi Aksara.

Sumantri, P. \& Permana, J. 1998. Strategi Belajar Mengajar. Jakarta: Depdikbud Dirjen Dikti.

Suprijono, A. 2011. Cooperative Learning. Surabaya: Pustaka Pelajar. 